\title{
ÚZEMNÉ PLÁNOVANIE V SR A VO VYBRANÝCH ŠTÁTOCH EÚ VO VZŤAHU K CITY LOGISTIKE
}

\section{SPATIAL PLANNING IN SLOVAKIA AND IN SELECTED EU COUNTRIES REGARDING CITY LOGISTICS}

Filip Škultéty1, ${ }^{*}$ Dominika Beňová2

\begin{abstract}
Abstrakt
Mestská logistika a City logistika sú súhrnnými pojmami pre vel'ké množstvo koncepcií spájania mestskej nákladnej dopravy a udržatel'nosti prostredníctvom znižovania negatívnych prevádzkových a environmentálnych javov. City logistika má naviac za úlohu redukovat' náklady na zásobovanie, znižovat' požiadavky na zdroje a zlepšovat' kvalitu života obyvatelov miest. Príspevok je venovaný problematike spojitosti medzi priestorovým plánovaním a rozvojom City logistiky. Ústrednou tézou je posúdenie implementácie logistických opatrení a logistických centier vo vzt'ahu $k$ územnému plánovaniu. Ciel' výskumu je komparatívna prípadová štúdia Slovenskej republiky a siedmych vybraných európskych krajín so zretel'om na city logistiku. V štúdií boli taktiež vyhodnocované city logistické opatrenia Amsterdamu, Berlína, Bratislavy, Helsínk, Kodane, Lisabonu, Paríza a Viedne, hlavných miest analyzovaných krajín.
\end{abstract}

Klíčová slova city logistika, územné plánovanie, mestá, Smart city, UCC

Summary Urban logistics and City logistics are collective terms for a large number of concepts combining urban freight transport and sustainability by reducing negative operational and environmental phenomena. In addition, city logistics has the task of reducing supply costs, resource requirements and improving the quality of life of city residents. The paper is devoted to the issue of relation between spatial planning and the development of City logistics. The central thesis is the assessment of the implementation of logistics measures and logistics centres considering spatial planning. The aim of the research is a comparative case study of the Slovak Republic and seven selected European countries with regard to logistics. The study also evaluated the approaches of logistical measures in Amsterdam, Berlin, Bratislava and Helsinki, Copenhagen, Lisbon, Paris and Vienna - the capitals of analysed countries.

Keywords city logistics, spatial planning, cities, Smart city, UCC

\section{1 ÚVOD}

City logistika je proces optimalizácie logistických a dopravných aktivít, ktorého sa zúčastňujú prepravcovia, zasielatelia, dopravcovia, a tiež orgány mesta s podporou pokročilých informačných systémov na území mesta s ohl'adom na dopravné prostredie a jeho vplyv na vznik kongescií, bezpečnost' a úspory energie (Akkad a Bányai, 2020). City logistika taktiež úzko súvisí s distribúciou a nutnost'ou

\footnotetext{
1 Žilinská univerzita v Žiline, Fakulta prevádzky a ekonomiky dopravy a spojov, Katedra leteckej dopravy, Univerzitná 8215/1, 01026 Žilina, Slovenská republika

2 Žilinská univerzita v Žiline, Fakulta prevádzky a ekonomiky dopravy a spojov, Katedra cestnej a mestskej dopravy, Univerzitná 8215/1, 01026 Žilina, Slovenská republika

* korespondenční autor: e-mail: filip.skultety@fpedas.uniza.sk
} 
systémového pohladu na otázky, ktoré úzko súvisia s nákladnou dopravou v mestských oblastiach, resp. v mestských zónach (Gnap, et al., 2020). City logistika je pre vel'ké aglomerácie nevyhnutná. Požiadavky zákazníkov na včasné doručovanie tovaru v rámci mesta sú čoraz vyššie, čo vedie k zvyšovaniu požiadaviek na logistiku a taktiež k väčšiemu počtu nákladných vozidiel (Wei, et al., 2020). Skúsenosti z praxe potvrdzujú, že je potrebné ucelene riešit' a zladit' všetky hmotné i nehmotné (peňažné, informačné a pod.) operácie v rámci výrobných a obehových procesov, ktoré vznikajú ako dôsledok del'by práce a sú spojené s výrobou, distribúciou určitého výrobku alebo tovaru. Tieto operácie sú navzájom previazané do logistických ret’azcov, ktorých východiskom je zistenie potrieb zákazníka po danom tovare či službe a na ich konci je dodanie. Konečným výsledkom je teda uspokojenie potrieb zákazníka a tým posilnenie pozície podniku na trhu pri ziskovosti. Konečný efekt musí byt' dosiahnutý s čo najväčšou pružnost’ou a hospodárnost'ou. Takýto prístup sa nazýva logistický. (Majerčák a Majerčák, 2015).

V súčasnosti mnohé európske mestá musia riešit' problémy súvisiace s nepriaznivou dopravnou situáciou. Skrúcaný a Kendra (2020) vyhodnocovali energetickú náročnost' a rastúcu produkciu emisií dopravného systému pri riešení problematiky dopravnej obsluhy miest. Tieto negatíva sú spôsobené z dôvodu zvyšujúceho sa počtu vozidiel, rozširovania územia miest, výstavby nových ulíc alebo obchodných centier. Dôležitým krokom zo strany miest je redukcia miery potrebnej dopravy práve v centrách a s tým súvisiace zníženie dopadov na životné prostredie pri zvýšení efektivity logistických ret'azcov. V prípade, ak je plánovaná a riadená doprava nastavená v mestách vhodne, tak môže ovplyvnit' úspešnost' logistiky a taktiež sa môže významne podiel'at' na dosiahnutí vytýčených ciel'ov. Na druhej strane nedostatky alebo pochybenia v doprave môžu vo vel'kej miere ovplyvnit' chod logistického systému a spôsobit' vznik nežiadúcich nákladov.

Zavádzanie city logistických opatrení môže mat' pozitívny vplyv na mestskú logistiku, môže prispiet' k zlepšeniu súčasného stavu dopravy v centrách miest, zníženiu emisií a teda k celkovému zlepšeniu kvality života $v$ centrách miest.

\section{2 ÚZEMNÉ PLÁNOVANIE V PODMIENKACH SR}

Súčast’ou územného plánovania je systém riadenia rozvoja spoločnosti. Je sústavnou činnost'ou, ktorá v súlade so základnými ciel’mi a úlohami národohospodárskych plánov komplexne rieši funkčné využitie územia, určuje zásady jeho organizácie a vecne i časovo koordinuje výstavbu a iné činnosti, ktoré ovplyvňujú rozvoj územia. Územné plánovanie sa zaoberá hmatatel'nými perspektívami prostredia, najmä zástavbou sídiel, technickou a dopravnou infraštruktúrou, ako aj prvkami životného prostredia (Coplák, 2019).

Ciel’om územného plánovania je posilňovat' na danom území poriadok a stanovené pravidlá. V mestách má územné plánovanie najmä regulačnú funkciu, zároveň stanovuje rámce prosperity, ktoré umožňujú na danom území určitú mieru vol’nosti, ale zamedzuje nežiadúcim vplyvom.

Ústredným orgánom územného plánovania je Ministerstvo dopravy, výstavby a regionálneho rozvoja SR, zatial' čo ekologické stanoviská územného plánovania sú v gescii Ministerstva životného prostredia SR. Územné plánovanie, najmä ako prostriedok starostlivosti o životné prostredie, postupne získavalo na význame predovšetkým $\mathrm{v}$ orgánoch samosprávy. Konkrétne náležitosti územného plánovania boli prostredníctvom zákona č. 237/2000 Z.z. presunuté na obce, samosprávne kraje a krajské stavebné úrady.

V súčasnosti na Slovensku platí novelizovaný Zákon č. 50/1976 Zb., (v znení neskorších predpisov) o územnom plánovaní a stavebnom poriadku (Stavebný zákon), v ktorého zmysle má územné plánovanie zákonom definovanú nasledujúcu štruktúru nástrojov:

- územnoplánovacie podklady,

- územnoplánovacia dokumentácia,

- územné rozhodnutie. 
Územnoplánovacie podklady podl’a zákona sú:

- urbanistická štúdia,

- územný generel,

- územná prognóza,

- územno-technické podklady.

Jedným z najdôležitejších nástrojov územného plánovania je územno-plánovacia dokumentácia (ÚPD). Územnoplánovacia dokumentácia je podl'a zákona zadefinovaná $\mathrm{v}$ nasledujúcich hierarchických úrovniach:

- Koncepcia územného rozvoja Slovenska (KURS),

- územný plán regiónu,

- územný plán obce,

- územný plán zóny.

Územné plánovanie vytvára požiadavky pre zabezpečenie trvalej súhry všetkých prírodných, civilizačných a kultúrnych aspektov v území, najmä so zameraním na starostlivost' o životné prostredie a ochranu jeho hlavných zložiek - pôdy, vody a ovzdušia (zákon č. 237/2000 Z. z.). Koncepcia územného rozvoja Slovenska sa vypracováva pre celé územie Slovenskej republiky. Rieši priestorové usporiadanie a funkčné využívanie územia Slovenskej republiky a ustanovuje rámec sociálnych, ekonomických, environmentálnych a kultúrnych požiadaviek štátu na územný rozvoj, starostlivost' o životné prostredie a tvorbu krajiny Slovenskej republiky a jej regiónov. Územno-technickým podkladom na jej spracovanie je Stratégia územného rozvoja Slovenska.

Mestá a obce majú rozhodujúcu úlohu v procese regulácie rozvoja územia. Sú obstarávatel'mi územnoplánovacej dokumentácie v rámci originálnej pôsobnosti. Zabezpečujú funkcie stavebných úradov v rámci preneseného výkonu štátnej správy na úseku územného plánovania, stavebného poriadku a bývania. Význam regulácie v územnom plánovaní a samotnom územnom pláne spočíva v tom, že regulatívy vlastne vytvárajú pravidlá pre využitie území, a z pohl'adu povol'ovania výstavby miestny stavebný poriadok (porovnáva sa súlad stavby s územným plánom). Regulačné nástroje definujú podmienky s presnost'ou na parcelu, kde definujú umiestnenie alebo využitie s ciel'om regulovat' využitie. V niektorých štátoch sú prepojené územné plány a regulačné plány v jeden dokument (Urbanista, 2018).

V tabul'ke 1 je uvedená kategorizácia územných plánovacích nástrojov uplatňovaných pri územnom plánovaní v podmienkach SR.

Tab. 1 Kategorizácia územných plánovacích nástrojov; zdroj: Autori

\begin{tabular}{llll}
\hline Typ nástroja & Účel & $\begin{array}{l}\text { Vymedzené } \\
\text { územie }\end{array}$ & Podskupiny \\
\hline $\begin{array}{l}\text { Štátna politika a } \\
\text { koncepcia }\end{array}$ & $\begin{array}{l}\text { Identifikácia štátnej politiky } \\
\text { a stratégií. }\end{array}$ & $\begin{array}{l}\text { Celý śtát alebo } \\
\text { určité územia. }\end{array}$ & $\begin{array}{l}\text { Národné stratégie; } \\
\text { Koncept územného } \\
\text { rozvoja }\end{array}$ \\
\hline Strategické nástroje & $\begin{array}{l}\text { Identifikácia širšej koncepcie } \\
\text { rozvoja územia na úrovni } \\
\text { nižšej ako celoštátny a vyšší } \\
\text { ako komunálny. Rieši } \\
\text { sociálno-ekonomickú politiku. }\end{array}$ & $\begin{array}{l}\text { Zodpovedá } \\
\text { administratívnemu } \\
\text { členeniu štátu. }\end{array}$ & $\begin{array}{l}\text { Nástroje strategického } \\
\text { plánovania; } \\
\text { Regionálne plány }\end{array}$ \\
& $\begin{array}{l}\text { Identifikácia všeobecných } \\
\text { zásad využitia územia. }\end{array}$ & $\begin{array}{l}\text { Väčšinou celé } \\
\text { územie mesta/obce. }\end{array}$ \\
\hline Územné plány & $\begin{array}{l}\text { Regulácia rozvoja na } \\
\text { jednotlivých parcelách. }\end{array}$ & $\begin{array}{l}\text { Od jednotlivého } \\
\text { pozemku, až k } \\
\text { celému mestu/ obci. }\end{array}$ & $\begin{array}{l}\text { Regulačné plány zón; } \\
\text { kástroje stavebného } \\
\text { Regulačné plány }\end{array}$ \\
& & & \\
\hline
\end{tabular}




\section{3 ÚZEMNÉ PLÁNOVANIE VO VYBRANÝCH ŠTÁTOCH EÚ}

Problematika efektívnosti fungovania, pružnosti a schopnosti reagovat' na aktuálne požiadavky a problémy, ktoré vychádzajú z praxe územného rozvoja je vo vzt’ahu $\mathrm{k}$ plánovacím systémom $\mathrm{v}$ manažmente územného rozvoja aktuálnou témou nielen v SR. Sprístupnenie a inteligentné využívanie potenciálu územia sa stalo rozhodujúcim faktorom udržatel'ného rozvoja, teritoriálnej kohézie a konkurencieschopnosti na všetkých úrovniach od národnej, cez regionálnu až po lokálnu úroveň a tiež zdôraznilo potrebu reflexie kontinentálnej Európskej úrovne vo všetkých týchto úrovniach (Urbanista,2018). Je potrebné vytvárat' podmienky pre zabezpečenie permanentnej súhry všetkých aktivít v území so zvláštnym dôrazom na starostlivost' o životné prostredie, dosiahnutie ekologickej stability a zabezpečenie udržatel'ného rozvoja, šetrné využívanie prírodných zdrojov a ochranu prírodných civilizačných a kultúrnych hodnôt (Finka, Petríková a Jamečný, 2008).

Územný manažment je ekonomicko-technický termín, ktorý charakterizuje priebeh riadenia správy pozemkov, ochrany územia a smerovania príslušných organizácií, prostredníctvom nasadenia a manipulácie pozemkových zdrojov. Ide o riadenie využitia územia (krajiny, pôdy) z ekonomického a ekologického hl'adiska (trvalo udržatel'ný rozvoj). Z funkčného hl'adiska predstavuje procesy zaoberajúce sa úpravami, meraniami a vykonávaním činností súvisiacich s pozemkami a územím. Koncept územia obsahuje nehnutel'nosti a prírodné zdroje a tým ovplyvňuje celkové prirodzené aj vybudované prostredie. Organizačné štruktúry pre územný manažment sa značne líšia medzi jednotlivými krajinami a regiónmi na celom svete a odrážajú miestne kultúrne a právne prostredie (DG Regio, 2000).

V tabul'ke 2 je uvedený prehl'ad typov nástrojov manažmentu priestorového rozvoja na celoštátnej úrovni vo vybraných štátoch EÚ a v tabul'ke 3 je uvedená kategorizácia územných plánovacích nástrojov.

Tab. 2 Prehl’ad typov nástrojov vo vybraných štátoch EÚ; zdroj: Autori na základe (DG Regio, 2000)

\begin{tabular}{llll}
\hline Typ nástroja & $\begin{array}{l}\text { Národné perspektívy alebo } \\
\text { plány }\end{array}$ & $\begin{array}{l}\text { Všeobecná } \\
\text { politická smernica }\end{array}$ & $\begin{array}{l}\text { Sektorové alebo } \\
\text { problémovo založené } \\
\text { smernice }\end{array}$ \\
\hline \multirow{2}{*}{ Účel } & $\begin{array}{l}\text { Zostavit’ široko poňatý model } \\
\text { územného rozvoja }\end{array}$ & $\begin{array}{l}\text { Stanovit' všeobecnú } \\
\text { politiku pre celý } \\
\text { štát }\end{array}$ & $\begin{array}{l}\text { Stanovit' politiku pre } \\
\text { špecifický obor, napr. } \\
\text { infraštruktúru }\end{array}$ \\
\hline & Rakúsko & Rakúsko & Rakúsko \\
& Dánsko & Dánsko & Dánsko \\
& Fínsko & Nemecko & Fínsko \\
Členské štáty & Francúzsko & Slovenská republika & Francúzsko \\
& Nemecko & & Nemecko \\
& Holandsko & & Holandsko \\
& Slovenská republika & & Portugalsko \\
& & & Slovenská republika \\
\hline
\end{tabular}

Národné perspektívy môžu byt' súčast’ou dokumentov ekonomického plánovania alebo regionálnej politiky. Každý štát má vo svojej kompetencií proces regulácie rozvoja územia. Táto regulácia územia môže byt' vykonávaná na základe právnych predpisov a noriem, ktoré sú prijímané na národnej úrovni alebo môže byt' upravovaná aj všeobecne záväznými nariadeniami zo strany samospráv. 
Tab. 3 Kategorizácia územných plánovacích nástrojov; zdroj: Autori

\begin{tabular}{|c|c|c|c|}
\hline Štát & Systém & Legislatíva & Obsah plánovacích nástrojov \\
\hline $\begin{array}{l}\text { Slovenská } \\
\text { republika }\end{array}$ & $\begin{array}{c}\text { Územno- } \\
\text { plánovací systém }\end{array}$ & $\begin{array}{l}\text { - Zákon o územnom } \\
\text { plánovaní, } \\
\text { - Stavebný poriadok }\end{array}$ & $\begin{array}{l}\text { - Určuje limity využitia územia, } \\
\text { - Reguluje funkčné a priestorové } \\
\text { usporiadanie územia, } \\
\text { - Sledovanie, vyhodnocovanie } \\
\text { a evidencia údajov a informácií } \\
\text { o území, } \\
\text { - } \quad \text { Prevádzkovanie informačného } \\
\text { systému o územnom plánovaní } \\
\text { a o výstavbe, } \\
\text { - Územnoplánovacia činnost', } \\
\text { ktorá tvorí obstarávanie, } \\
\text { spracovanie a aktualizáciu } \\
\text { územnoplánovacích podkladov } \\
\text { a územnoplánovacej } \\
\text { dokumentácie, } \\
\text { - Rozhodovanie v územnom } \\
\text { konaní. }\end{array}$ \\
\hline Holandsko & $\begin{array}{l}\text { Priestorový } \\
\text { rozvoj }\end{array}$ & $\begin{array}{l}\text { - Zákon } \\
\text { o priestorovom } \\
\text { plánovaní, } \\
\text { - Zákon o rozvoji, } \\
\text { - Zákon o mestách } \\
\text { a životnom prostredí }\end{array}$ & $\begin{array}{l}\text { Ministerstvo pre bývanie, } \\
\text { priestorové plánovanie a } \\
\text { životné prostredie je } \\
\text { zodpovedné za priestorovú } \\
\text { štruktúru. Na celoštátnej úrovni } \\
\text { koordinuje implementáciu } \\
\text { projektov celoštátneho } \\
\text { významu. }\end{array}$ \\
\hline Nemecko & $\begin{array}{c}\text { Priestorovo } \\
\text { plánovací systém }\end{array}$ & $\begin{array}{l}\text { - Stavebný poriadok, } \\
\text { - Zákon } \\
\text { o priestorovom } \\
\text { usporiadaní, } \\
\text { - Zákony o krajinskom } \\
\text { plánovaní }\end{array}$ & $\begin{array}{l}\text { - Znázornenie spôsobu } \\
\text { funkčného využitia územia, } \\
\text { - } \quad \text { Ustanovenia pre } \\
\text { urbanistické usporiadanie, } \\
\text { - Zásady priestorového } \\
\text { usporiadania, } \\
\text { - } \quad \text { Ciele priestorového } \\
\text { usporiadania a krajinského } \\
\text { plánovania }\end{array}$ \\
\hline Rakúsko & $\begin{array}{l}\text { Priestorové } \\
\text { usporiadanie }\end{array}$ & $\begin{array}{l}\text { - Zákon } \\
\text { o priestorovom } \\
\text { usporiadaní, } \\
\text { - Stavebný poriadok, } \\
\text { - Zákon o obecnom } \\
\text { plánovaní }\end{array}$ & 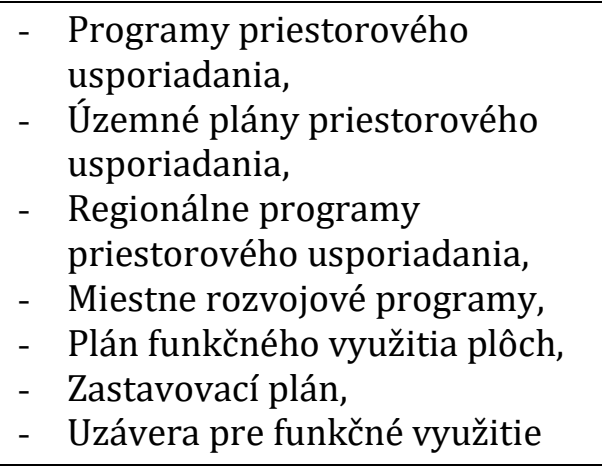 \\
\hline Portugalsko & $\begin{array}{l}\text { Priestorové } \\
\text { plánovanie }\end{array}$ & $\begin{array}{l}\text { - Zákon o } \\
\text { priestorovom } \\
\text { plánovaní 48/98, } \\
\text { - Zákon } 380 / 99 \text { o } \\
\text { režime funkčného }\end{array}$ & $\begin{array}{l}\text { - Rámec pre politiku v oblasti } \\
\text { priestorového a mestského } \\
\text { plánovania, } \\
\text { - Systém územného manažmentu. } \\
\text { - Regulácia, v rámci politiky } \\
\text { vertikálnych a horizontálnych }\end{array}$ \\
\hline
\end{tabular}




\begin{tabular}{|c|c|c|c|}
\hline & & $\begin{array}{l}\text { využitia územia } \\
\text { a postupoch } \\
\text { plánovania }\end{array}$ & $\begin{array}{l}\text { vzt'ahov medzi rôznymi } \\
\text { úrovňami a sektormi verejnej } \\
\text { administratívy, } \\
\text { - Vytváranie priestoru k } \\
\text { participácii obyvatel'ov, } \\
\text { sociálnych a ekonomických } \\
\text { stakeholderov }\end{array}$ \\
\hline Fínsko & $\begin{array}{l}\text { Priestorové } \\
\text { plánovanie }\end{array}$ & $\begin{array}{l}\text { - Zákon o funkčnom } \\
\text { využití územia a } \\
\text { stavebnom poriadku }\end{array}$ & $\begin{array}{l}\text { - Definuje základné ciele a smery } \\
\text { priestorového rozvoja vo Fínsku } \\
\text { vo väzbe na zákonom } \\
\text { definované všeobecné ciele pre } \\
\text { plánovanie funkčného využitia } \\
\text { územia. Premieta sa do } \\
\text { špecifikovaných požadovaných } \\
\text { obsahov plánovacej } \\
\text { dokumentácie na nižších } \\
\text { úrovniach plánovania. }\end{array}$ \\
\hline Dánsko & $\begin{array}{c}\text { Priestorovo } \\
\text { plánovací systém }\end{array}$ & $\begin{array}{l}\text { - Zákon o plánovaní, } \\
\text { - Stavebný poriadok, } \\
\text { - Zákon o parcelácii, } \\
\text { - Zákon o } \\
\text { urbanistickej } \\
\text { revitalizácii a } \\
\text { rozvoji, } \\
\text { - Zákon o výstavbe }\end{array}$ & $\begin{array}{l}\text { - Optimálny rozvoj celého štátu a } \\
\text { jednotlivých administratívnych } \\
\text { regiónov a obcí založený na } \\
\text { všeobecných a ekonomických } \\
\text { požiadavkách, } \\
\text { - } \quad \text { Vytvorenie a ochrana cenných } \\
\text { budov, osídlení, urbanistických } \\
\text { komplexov a krajiny, } \\
\text { - Ochrana otvorených } \\
\text { pobrežných oblastí ako } \\
\text { dôležitých prírodných } \\
\text { a krajinných zdrojov, } \\
\text { - Prevencia znečistenia ovzdušia, } \\
\text { vody a pôdy a prevenciu } \\
\text { zat'aženia hlukom, } \\
\text { - Zapojenie verejnosti do } \\
\text { plánovacích procesov v } \\
\text { maximálnej možnej miere. }\end{array}$ \\
\hline Francúzsko & $\begin{array}{l}\text { Priestorové } \\
\text { plánovanie }\end{array}$ & $\begin{array}{l}\text { - Zákon } \\
\text { o priestorovom } \\
\text { plánovaní a rozvoji, } \\
\text { - Zákon o regionálnom } \\
\text { plánovaní }\end{array}$ & $\begin{array}{l}\text { - Zabezpečenie rozvoja miest, } \\
\text { vidieckych území, pobrežných } \\
\text { území a horských regiónov, } \\
\text { - Podpora všetkých častí } \\
\text { Francúzska v rozvoji } \\
\text { konkurencieschopnej } \\
\text { infraštruktúry, ktorá je } \\
\text { rozhodujúca pre rozvoj, } \\
\text { - Podpora hodnotných území a } \\
\text { aplikácia manažmentu } \\
\text { funkčného využitia územia } \\
\text { na ochranu hodnôt týchto } \\
\text { území. }\end{array}$ \\
\hline
\end{tabular}




\section{LEGISLATÍVA OVPLYVŇUJÚCA MESTSKÚ LOGISTIKU V SR}

Na území SR ovplyvňujú mestskú logistiku v oblasti prepravy tovaru v prevažnej miere nástroje regulácie cestnej nákladnej dopravy. V súčasnosti jediným zavedeným legislatívnym nástrojom regulácie cestnej nákladnej dopravy v mestách je zákon NR SR č. 8/2009 Z. z. o cestnej premávke a o zmene a doplnení niektorých zákonov v znení neskorších zmien a doplnkov. Zákon upravuje pravidlá cestnej premávky, práva a povinnosti osôb v súvislosti s cestnou premávkou, pôsobnost' orgánov verejnej správy na úseku organizácie riadenia cestnej premávky, atd'.

V SR sa aplikujú rôzne prístupy k regulácii cestnej nákladnej dopravy. Najčastejšie je to obmedzovanie vjazdu resp. prejazdu cestnej nákladnej dopravy pomocou dopravného značenia. Do pešej zóny je povolený vjazd len vozidlám, ktorým to umožňuje dopravná značka. V SR sa dá použit' len nasledovná právna úprava: nakladanie a skladanie nákladu na ceste je dovolené len vtedy, ak to nemožno urobit’ mimo cesty. Náklad sa musí zložit' a naložit', čo najrýchlejšie a tak, aby nebola ohrozená bezpečnost' cestnej premávky (Zákon č.8/2009 Z.z.)

Európska norma, ktorá bola prevzatá do nášho systému je norma STN EN 14892 s názvom „Prepravné služby - Logistika mesta." Norma definuje možné obmedzenia prístupu do vel'kých miest s mestskými centrami, obchodnými zónami a inými uzavretými pásmami/plochami a poskytuje pokyny pre prvky, ktorých ciel' je vytvorit' rozhranie medzi dopravnými nákladnými spoločnost’ami a miestnymi úradmi s ciel’om účinnejšieho plánovania prepravy a prevádzky, na vyvarovanie sa úzkym (problémovým) miestam v oblasti a na ochranu životného prostredia mesta.

Medzi nástroje regulácie cestnej nákladnej dopravy na území SR sa využívajú časové obmedzenia, t.j. časové obmedzenia pre vjazd do centra mesta, resp. do pešej zóny a vjazd je povolený len pre určitú kategóriu vozidiel. Vd'aka zákonu o ovzduší č. 137/2010 Z.z. môžu samosprávne kraje, mestá, obce regulovat' vjazd vozidiel do centra mesta s ohl'adom na ich emisné charakteristiky. Mestá budú môct' vymedzit' určité oblasti (zóny), v ktorých by v prípade vel'kého znečistenia ovzdušia mohli obmedzit' vjazd určitej kategórie motorových vozidiel.

\section{LEGISLATÍVA OVPLYVŇUJÚCA MESTSKÚ LOGISTIKU V EÚ}

V rámci Európskej únie v značnej miere ovplyvňujú mestskú logistiku rôzne strategické dokumenty, predpisy. Európska komisia (EK) schválila Bielu knihu s názvom Plán jednotného európskeho dopravného priestoru - Vytvorenie konkurencieschopného systému efektívne využívajúceho zdroje do roku 2030 2050. Ciele dopravnej politiky EÚ v oblasti mestskej logistiky sú tiež vel'mi ambiciózne. Znížit' používanie konvenčne poháňaných automobilov v mestskej doprave do roku 2030 na polovicu, postupne ich vyradit' z premávky v mestách do roku 2050, dosiahnut' v centrách vel'kých miest zavedenie mestskej logistiky v podstate bez emisií $\mathrm{CO}_{2}$ do roku 2030 . K tomuto ciel'u musí prispiet' aj mestská logistika v oblasti prepravy nákladu. Okrem emisií z výfukových plynov v oblasti najmä nočnej distribúcie je dôležitým aspektom hluk z dopravy (Európska Komisia, 2011). Európska komisia v roku 2007 prijala Zelenú knihu - Na ceste k novej kultúre mestskej mobility. Vd’aka Zelenej knihe Komisia stanovila novú európsku agendu pre mestskú mobilitu a súčasne by rešpektovala zodpovednost’ miestnych, regionálnych a národných orgánov v tejto oblasti. Nárast dopravy v centrách miest v celej Európe vedie k pravidelnému pret'aženiu ciest, k mnohým neblahým dôsledkom, pokial' ide o stratu času a poškodzovanie životného prostredia. Znečist'ovanie atmosféry a hlučnost' sa každý rok zintenzívňujú. Z dopravy v meste pochádza $40 \%$ emisií $\mathrm{CO}_{2}$ a $70 \%$ emisií iných znečist'ujúcich látok, ktoré vznikajú pri cestnej doprave (Európska Komisia, 2007).

Nízko emisná mobilita predstavuje základnú zložku širšieho prechodu na nízko-uhlíkové, obehové hospodárstvo, ktoré Európa potrebuje, aby zostala konkurencieschopnou a aby mohla uspokojovat' potreby v oblasti mobility osôb a tovarov. Z dopravy pochádza takmer štvrtina emisií skleníkových plynov v Európe a je hlavnou príčinou znečist’ovania ovzdušia v mestách. Odpoved’ou Európy na tieto výzvy je nezvratný prechod na mobilitu s nízkymi emisiami uhlíka a látok znečist’ujúcich ovzdušie. Doprava má v 
porovnaní s minulost'ou ovel'a väčší potenciál prispievat' k znižovaniu emisií EÚ, k čomu sa SR zaviazala v rámci Parížskej dohody o zmene klímy a v súlade s programom trvalo udržatel'ného rozvoja do roku 2030 (Európska Komisia, 2017).

\section{CITY LOGISTICKÉ OPATRENIA VO VYBRANÝCH ŠTÁTOCH EÚ}

V zahraničí je city logistika vnímaná ako aplikácia overených spôsobov regulácie dopadov dopravy v mestských zónach. Avšak je nevyhnutné prihliadat’ k individualite jednotlivých problémov, ale zároveň i mestskému prostrediu. Nie je vhodné vziat' jedno konkrétne logistické opatrenie (Russo and Comi, 2020) a použit' ho bez toho, aby bolo prispôsobené konkrétnym podmienkam v jednotlivých štátoch alebo mestách. Kladie sa vel'ký dôraz na kvalitu a vysokú úroveň poskytovaných služieb, preto je aplikácia optimalizácie v logistických procesoch nevyhnutnost’ou.

Graf na obr. 1 znázorňuje percentuálne vyjadrenie city logistických opatrení aplikovaných vo všetkých členských štátoch Európskej únie. Vo viac ako 50\% európskych hlavných miest sa implementujú tieto typy opatrení, a to: cargo bicykle, hmotnostné a časové obmedzenie pre vozidlá vykonávajúce distribúciu do centra mesta. Cargo bicykle používané na vykonávanie distribúcie tovaru do centra mesta využíva vo svojich hlavných mestách 22 štátov (81\%), hmotnostné obmedzenie pre vjazd do centra mesta má na svojom území aplikovaných 17 štátov (63\%) a časové obmedzenie pre vjazd do centra svojho mesta má zavedených 15 štátov (56\%). Medzi d’alšie často využívané city logistické opatrenia patria aj výstavba mestských konsolidačných centier (UCC) a zavádzanie nízko emisných zón.

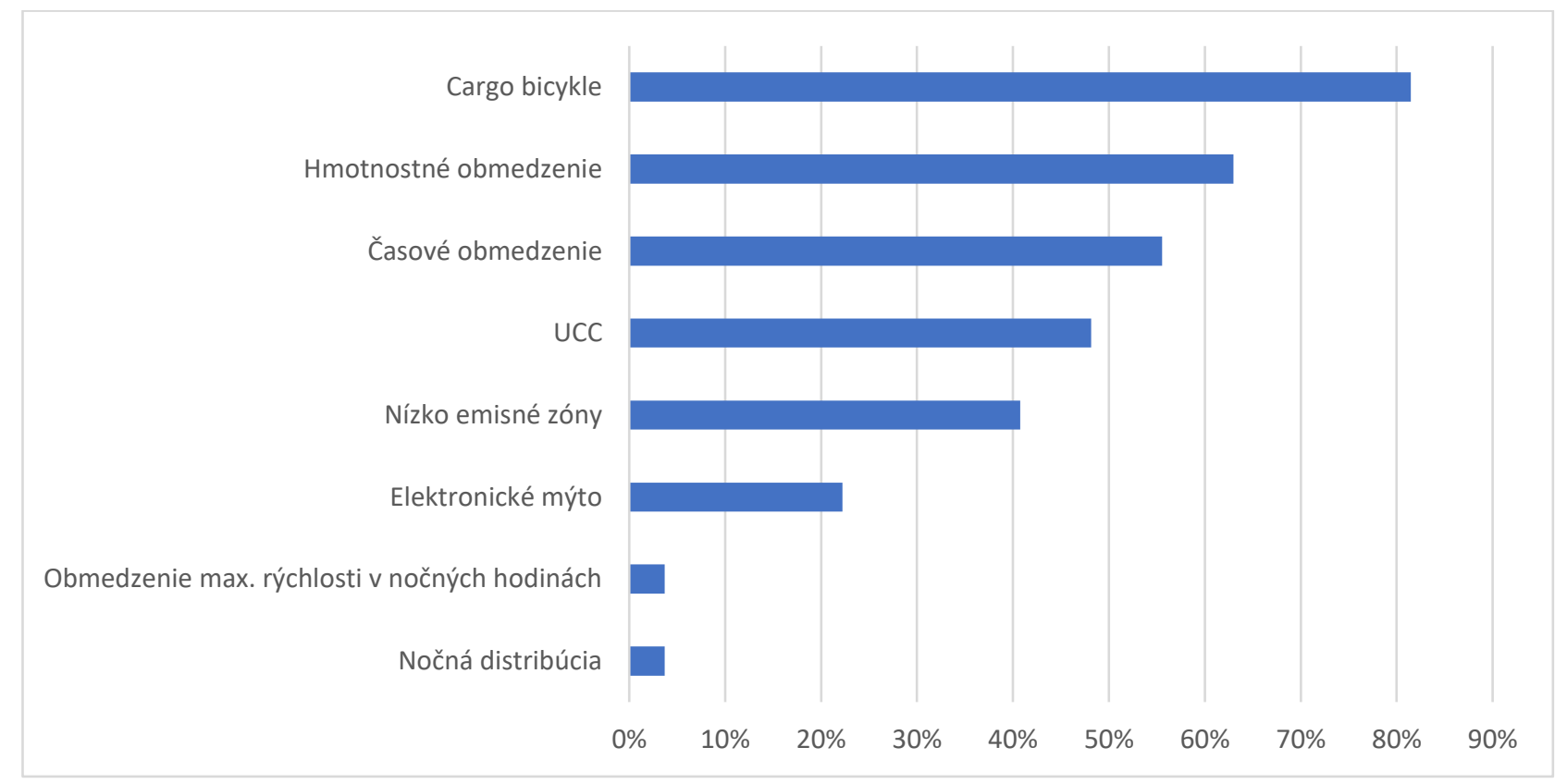

Obr. 1 Podiel aplikovaných city logistických opatrení; zdroj: Autori

V tabul'ke 4 je uvedený prehl’ad city logistických opatrení, ktoré sú aplikované vo vybraných štátoch EÚ a ovplyvňujú distribúciu tovaru do centra miest. V niektorých mestách sú implementované rôzne kombinácie logistických riešení pre trvalo udržatel'né mesto. Trvalo udržatel'ný rozvoj mesta je založený na troch základných princípoch a to na hodnotení navrhovaných riešení identifikovaných problémov z hl'adiska environmentálneho, ekonomického i sociálneho dopadu a súčasne na efektívnom zapojení verejnosti do procesu rozvoja mesta. 
Tab. 4 Prehl'ad city logistických opatrení vo vybraných štátoch EÚ; zdroj: Autori

\begin{tabular}{|c|c|c|c|c|c|c|c|c|}
\hline & $\begin{array}{l}\text { Nízko } \\
\text { emisné } \\
\text { zóny }\end{array}$ & $\begin{array}{l}\text { Hmotnostné } \\
\text { obmedzenie }\end{array}$ & $\begin{array}{c}\text { Časové } \\
\text { obmedzenie }\end{array}$ & UCC & $\begin{array}{l}\text { Elektronické } \\
\text { mýto }\end{array}$ & $\begin{array}{c}\text { Nočná } \\
\text { distribúcia }\end{array}$ & $\begin{array}{l}\text { Obmedzenie } \\
\text { rýchlosti } \\
\text { v nočných } \\
\text { hodinách } \\
\end{array}$ & $\begin{array}{c}\text { Cargo } \\
\text { bicykle }\end{array}$ \\
\hline Rakúsko & $\checkmark$ & $\checkmark$ & $\checkmark$ & $\checkmark$ & $x$ & $x$ & $\checkmark$ & $\checkmark$ \\
\hline $\begin{array}{l}\text { Slovenská } \\
\text { republika }\end{array}$ & $x$ & $\checkmark$ & $\checkmark$ & $x$ & $x$ & $x$ & $x$ & $\checkmark$ \\
\hline Dánsko & $\checkmark$ & $x$ & $x$ & $\checkmark$ & $x$ & $x$ & $x$ & $\checkmark$ \\
\hline Fínsko & $\checkmark$ & $\checkmark$ & $x$ & $\checkmark$ & $x$ & $x$ & $x$ & $\checkmark$ \\
\hline Francúzsko & $\checkmark$ & $\checkmark$ & $\checkmark$ & $\checkmark$ & $x$ & $x$ & $x$ & $\checkmark$ \\
\hline Holandsko & $\checkmark$ & $\checkmark$ & $\checkmark$ & $\checkmark$ & $x$ & $x$ & $x$ & $\checkmark$ \\
\hline Nemecko & $\checkmark$ & $\checkmark$ & $x$ & $\checkmark$ & $x$ & $x$ & $x$ & $\checkmark$ \\
\hline Portugalsko & $\checkmark$ & $x$ & $x$ & $\checkmark$ & $x$ & $x$ & $x$ & $\checkmark$ \\
\hline
\end{tabular}

Z tabul'ky 4 vyplýva, že najčastejšie aplikované city logistické riešenia vo vybraných štátoch EÚ sú UCC, nízko emisné zóny a distribúcia tovaru do centra mesta prostredníctvom cargo bicyklov.

UCC tvorí bránu medzi dial'kovou dopravou a tzv. zásobovaním na poslednej míli. V ideálnom prípade je dial'ková doprava realizovaná za pomoci kapacitných dopravných systémov, obvykle s využitím železničnej alebo vodnej dopravy. V praxi sa však stále viac objavujú prípady, kedy je UCC napojené iba na cestnú infraštruktúru. Po doručení tovaru do UCC dôjde k vykládke a následne ku konsolidácií na menšie dodávkové vozidlá, ktoré sú optimálne vybavené ekologickým pohonom. Potom prichádza na realizáciu samotného zásobovania na poslednej míli.

Nízko-emisné zóny (LEZ) sú oblasti, v ktorých sa od vozidiel vyžaduje určitá emisná norma a do ktorých majú vozidlá nespíňajúce tieto normy zakázaný vjazd. Niektoré LEZ môžu obmedzit’ len určité kategórie vozidiel (t’ažké nákladné, l'ahké nákladné). Budovanie nízko-emisných zón v Európe znižuje zát’až územia emisiami výfukových plynov a zlepšuje kvalitu života obyvatel'ov v tejto oblasti. Implementácia LEZ má zásadný význam pre kvalitu ovzdušia a legislatívne opatrenia na zníženie emisií znečist'ujúcich ovzdušie (Santos, et al., 2019). Campbell a Roberts (2019) opätovne preskúmali zdravotné dôsledky spojené s implementáciou LEZ. V rámci EÚ je tento druh regulácie cestnej nákladnej dopravy populárny a mestá využívajú v prevažnej miere geograficky vyčlenené oblasti, čím sa má znížit' počet vozidiel vstupujúcich do centra.

Distribúcia tovaru do centra mesta prostredníctvom cargo bicyklov v rámci EÚ je v dnešnej dobe najrozšírenejším a najpopulárnejším nízkonákladovým nástrojom pre distribúciu (Assmann, et al., 2018). Cargo bicykle sú špeciálne dvojkolesové dopravné prostriedky, ktoré sú prispôsobené svojou konštrukciou na distribúciu zásielok, resp. tovaru. Tieto cargo bicykle môžu byt' vybavené aj elektromotorom.

Každé mesto v rámci EÚ je jedinečné, avšak všetky väčšie mestá riešia problémy súvisiace s dopravnými zápchami, kvalitou vzduchu, počtom vozidiel v centrách miest, ale aj nehodovost'ou, bezpečnost'ou. Jednou z odpovedí na dané problémy je prechod na „Smart Cities“. Koncept inteligentného mesta Smart city využíva všetky dostupné možnosti a moderné informačné technológie tak, aby logistika, doprava, ale aj život obyvatel'ov boli čo na najvyššej úrovni (Russo et. al., 2016). Pre koncept Smart city sú kl'účové práve dopravné riešenia, ktoré reflektujú ich udržatel'nost', reálnost' nasadenia do prevádzky, ale najmä vyššiu bezpečnost' a znižovanie environmentálnych dopadov.

Graf na Obr. 2 znázorňuje Smart city skóre na základe, ktorého sú posudzované vybrané mestá EÚ na základe názorov svojich obyvatel'ov vo vzt'ahu k mobilite v danom meste. Na obrázku sú d’alej znázornené kongescie a emisie $\mathrm{CO}_{2}$, ktoré majú vplyv nielen na city logistiku, dopravu v centrách miest, ale aj život 
obyvatel’ov. Mesto Helsinki má z vybraných štátov EÚ najvyššie Smart city hodnotenie, má najnižšiu úroveň kongescií a zároveň aj emisií $\mathrm{CO}_{2}$. Naopak Bratislava je z pomedzi porovnávaných miest hodnotená najhoršie. Z grafu je možno vidiet', že mestá Paríž a Lisabon majú z pomedzi porovnávaných miest najvyššie kongescie, ktoré vyplývajú z vysokej koncentrácie obyvatel'stva na relatívne malom území. V takýchto prípadoch je potrebné zvýšit' pozornost' a zamerat' sa práve na implementáciu logistických opatrení.

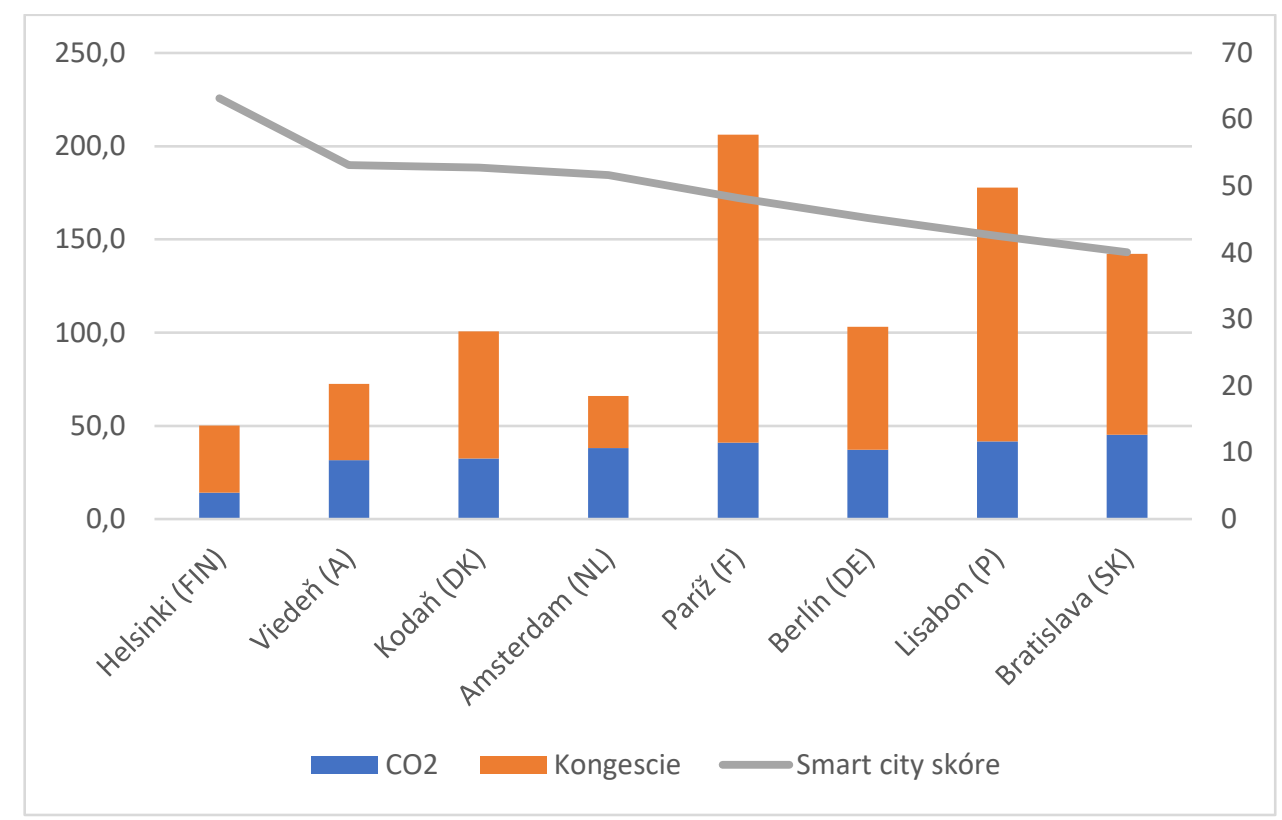

Obr. 2 Skupinový graf Smart city skóre, $\mathrm{CO}_{2}$, kongescie; zdroj: Autori

V súčasnej dobe, kedy dopyt po logistických službách neustále rastie Smart logistika zaujala nezastupitel'né miesto. Zákazník je čoraz náročnejší na ponúkané služby, a tak je potrebná neustála modernizácia a optimalizácia logistických procesov, súvisiacich s tokom materiálu, informácií a financií. Centralizácia činností do logistických parkov je efektívna nielen z časového hl'adiska, ale aj z ekonomického a tiež ekologického (Gnap et. al., 2019). Zákazníkovi tak môžu byt' ponúknuté služby na jednom mieste, čo šetrí čas, peniaze a rovnako to priaznivo vplýva na životné prostredie, pretože sa znižujú dopravné výkony (Stopka et. al., 2020) a tým aj množstvo skleníkových plynov. Dôležitým faktorom pre úspešnú logistiku v centre mesta je vhodné umiestnenie priemyselných zón, logistických centier (Kubasáková et al., 2018). Preto je potrebné, aby si mestá vo svojich územných plánoch vyčlenili územia, resp. pozemky pre výstavbu priemyselných zón, pozemky pre skladovanie a logistiku.

Problém pri hl'adaní plôch, resp. pozemkov pre rozvoj logistiky v každom meste je problematické, nakol'ko mestá majú vo svojom vlastníctve už obmedzené množstvo plôch (Skrabal, 2020). Preto je do budúcna potrebné zanechat' v územnom pláne miest plochy, pozemky pre logistické činnosti. Príležitost'ou pre mestá je predovšetkým ucelený rozvoj rady „brownfieldových“ plôch, tu sa však aktuálne industriálne projekty presadit’ nedokážu. Viacero „brownfieldov“ sa nachádza vo vel’mi atraktívnych lokalitách, ktoré sa nachádzajú v blízkosti centra mesta a sú teda svojim umiestením predovšetkým zaujímavé pre developerov. Problémom rozvoja je aj neflexibilný územný plán miest a zároveň aj rôzne dížky schval'ovacích procesov.

„Brownfieldy“ sú aktuálne vel'mi lákavé pre investorov rezidentských projektov. Priemysel tieto plochy opustil, priemyselné objekty vrátane rozsiahlych skladových priestorov boli v prevažnej miere zdemolované, železničné vlečky boli poškodené alebo zrušené, napriek tomu je v dnešnej dobe vel'ký dopyt po týchto logistických areáloch v centrách miest. Ukázalo sa, že umiestnenie logistických areálov výhradne na okrajoch miest nie je ideálne. Vd’aka dnešnej situácií na trhu s nehnutel'nost’ami sa „brownfieldy“ 
pretvárajú práve na obytné, prípadné administratívne účely. Z pohl’adu trvalo udržatel'nej logistiky je toto aktuálne vnímané ako vel'ký problém, obzvlášt' v prípade, ked' plochy, ktoré sú určené pre logistiku $\mathrm{v}$ centre mesta sú už využívané iným spôsobom (Bartke. et al., 2016).

\section{ZÁVER}

Logistické centrá sú definované zákonom NR SR č. 193/2001 Z. z. ako „regionálny dodávatel'skoodberatel'ský uzol, ktorý poskytuje zákazníkom dopravné a manipulačné služby spojené so všestranným zabezpečením výroby a predaja výrobkov“. Avšak okrem vymedzenia logistických centier zákon nedefinuje mestskú a city logistiku. Na základe prípadovej štúdie bola zhodnotená implementácia celkovo ôsmych rôznych city logistických opatrení v Slovenskej republike a v d'alších európskych krajinách. Dôležitým nástrojom znižovania negatívnych vplyvov z dopravy v centrách miest je zavedenie nízkoemisných zón. LEZ opatrenie aplikovali všetky vyhodnocované mestá okrem Bratislavy. Slovenská republika navyše nezaviedla ani výstavbu mestských konsolidačných centier. Elektronické mýto a nočnú distribúciu doposial' nezaviedlo ani jedno z porovnávaných miest. Na druhej strane všetky mestá využívajú koncept komplementárneho zásobovania prostredníctvom cargo bicyklov. Viedeň na rozdiel od ostatných miest využíva obmedzenie rýchlosti v nočných hodinách.

V kontexte územného plánovania miest je možné konštatovat', že skúmané krajiny využívajú obdobné nástroje regulácie využívania mestských plôch podobe platných legislatívnych úprav na národnej a regionálnej úrovni. Z perspektívy smart city hodnotenia miest najlepšie skóre získali Helsinki, ktoré mali zároveň najnižšiu úroveň kongescií a aj emisií $\mathrm{CO}_{2}$ vyprodukovaných z dopravy. Ďalšia štúdia bude pokračovat' prostredníctvom zberu informácii a následnej analýzy všetkých 27 členských štátov EÚ.

Územné plány je potrebné vo vzt’ahu k logistike vypracovat’ tak, aby reflektovali na aktuálnu situáciu so zretel’om na budúci vývoj. Do procesu územného plánovania je možné aplikovat' viaceré princípy, ktoré v značnej miere ovplyvnia budúci vývoj logistických systémov. Takéto postupy zohl’adňujú napríklad kontakt s budúcim iniciátorom (investorom) logistického centra, ktorý umožní lepšie prispôsobenie profilu aktivít v centre mesta. Je potrebné uviest', že v procese plánovania sa musia brat' do úvahy rôzne aspekty budúcich služieb a činností logistického centra, ale aj ich vplyv na ostatné oblasti akými sú napríklad dopravné služby, dopravná infraštruktúra, či ochrana životného prostredia. Hlavné črty takéhoto územného plánovania by mali byt' zamerané na implementáciu v praxi, proaktívny prístup, horizontálnu a vertikálnu koordináciu, spoluprácu v oblasti komplementarity a synergiu.

\section{Literatúra}

Akkad, M., Bányai, T. 2020. Multi-Objective Approach for Optimization of City Logistics Considering Energy Efficiency. Sustainability, 12(18), s. 7366. Dostupné z: https://doi.org/10.3390/su12187366

Assmann, T.; Bobeth, S.; Fischer, E. 2018. A Conceptual Framework for Planning Transhipment Facilities for Cargo Bikes in Last Mile Logistics. Data Analytics: Paving the Way to Sustainable Urban Mobility Advances in Intelligent Systems and Computing, 575-582. Dostupné z: https://link.springer.com/chapter/10.1007\%2F978-3-030-02305-8_69

Bartke, S.; Martinát, S.; Klusáček, P.; Pizzol, L.; Alexandrescu, F.; Frantál, B.; Critto, A.; Zabeo, A. 2016. Targeted selection of brownfields from portfolios for sustainable regeneration: User experiences from five cases testing the Timbre Brownfield Prioritization Tool. Journal of Environmental Management, 184, 94107. Dostupné z: https://doi.org/10.1016/j.jenvman.2016.07.037

Campbell, T.; Roberts, N. 2019. The impacts low emission zones have on improving health and decreasing health inequalities. Asthma Epidemiol. Underst. Probl., 171, Dostupné z: https://thorax.bmj.com/content/74/Suppl_2/A171.2 
Coplák J. 2019. Čo je to územný plán. Územnéplány.sk [online]. Dostupné z: https://www.uzemneplany.sk/co-je-to-uzemny-plan [cit.: 15.01.2021].

DG for Regional and Urban Policy, 2000. The EU compendium of spatial planning systems and policies. [ebook] Dostupné z: <https://op.europa.eu/en/publication-detail/-/publication/a7342edc-968b-43d3bf51-d0cc42bc7642> [cit.: 18.01.2021].

Európska Komisia. 2007. Zelená kniha - Za novú kultúru mestskej mobility. Brusel.

Európska Komisia. 2011. Biela kniha - Plán jednotného európskeho dopravného priestoru - Vytvorenie konkurencieschopného dopravnému systému efektívne využívajúceho zdroje. Brusel.

Európska Komisia. 2017. Oznámenie Komisie Európskemu parlamentu, Rade, Európskemu hospodárskemu a sociálnemu výboru a výboru regiónov. Brusel.

Finka, M., Petríková, D. and Jamečný, L., 2008. Analýza právnych predpisov územného plánovania štátov EÚ ako podklad pre tvorbu územnoplánovacej legislatívy v SR. [ebook] Bratislava: CPTŠ. Dostupné z: <http://www.ochranari.sk/wp-

content/uploads/2013/10/CPTS_Urbion_prav_predpisy_UP_EU_analyza.pdf> [cit.: 16.01. 2021].

Gnap, J., Beňová, D., Digáňová, S. 2019. City logistics in the Slovak Republic. Svet dopravy, č. 1, s. 50-59. Dostupné z: http://www.svetdopravy.sk/city-logistika-na-uzemi-slovenskej-republiky/

Gnap, J., Beňová, D., Tuková, P. 2019. Logistics centers and logistics parks in Slovak Republic. Svet dopravy, č. 2, s. 11-18. Dostupné z: http://www.svetdopravy.sk/logisticke-centra-a-logisticke-parky-na-uzemislovenskej-republiky/

Kubasáková, I., Kubáňová, J., Stopka, O., Zeman, K. 2018. Services of logistics centers and parks, operators and infrastructure in Slovakia 2017, Proceedings of 8th international scientific conference CMDTUR 2018, s. $148-153$.

Majerčák, J., Majerčák, P. 2015. Logistika; ISBN 978-80-8181-019-0; 1st ed.; DOLIS: Bratislava, Slovakia.

Russo, F., Rindone, C., Panuccio, P. 2016. European plans for the smart city: From theories and rules to logistics test case. Eur. Plan. Stud., 24, 1709-1726. Dostupné z: https://doi.org/10.1080/09654313.2016.1182120

Russo, F., Comi, A. 2020. Investigating the Effects of City Logistics Measures on the Economy of the City. Sustainability, 12(4), p.1439. Dostupné z: https://doi.org/10.3390/su12041439

Santos, F. M.; Gómez-Losada, Á.; Pires, J. C. 2019. Impact of the implementation of Lisbon low emission zone on air quality. Journal of Hazardous Materials, 365, 632-641. Dostupné z: https://doi.org/10.1016/j.jhazmat.2018.11.061

Skrabal, J. 2020. What can we learn from brownfield databases? Exploring specifics of the location of brownfields in the czech republic. Geographia technica, 15(2), s. 191-201. Dostupné z: http://dx.doi.org/10.21163/GT_2020.152.18

Skrúcaný, T., Kendra, M. 2020. Vyhodnotenie energetickej náročnosti a produkcie emisií dopravného systému pri riešení problematiky dopravnej obsluhy miest a regiónov. Verejná osobná doprava - VOD 2020 : zborník prednášok z medzinárodnej konferencie, s. 49-54

Slovenská republika. 1976. Zákon č. 50/1976 Zb., Zákon o územnom plánovaní a stavebnom poriadku (stavebný zákon), v znení neskorších predpisov. Zbierka zákonov Slovenskej republiky.

Slovenská republika. 2000. Zákon č. 237/2000 Z.z., Zákon o územnom plánovaní a stavebnom poriadku (stavebný zákon), v znení neskorších predpisov. Zbierka zákonov Slovenskej republiky.

Slovenská republika. 2009. Zákon č. 8/2009 Z.z., Zákon o cestnej premávke a o zmene a doplnení niektorých zákonov. Zbierka zákonov Slovenskej republiky. 
Slovenská republika. 2010. Zákon č. 137/2010 Z.z., Zákon o ovzduší, v znení neskorších predpisov. Zbierka zákonov Slovenskej republiky.

Stopka, O., Jerabek, K., Stopkova, M. 2020. Using the Operations Research Methods to Address Distribution Tasks at a City Logistics Scale, Transportation Research Procedia, 44, s. 348-355. Dostupné z: https://doi.org/10.1016/j.trpro.2020.02.032

Urbanista. 2018. Inšpirácia z právneho prostredia manažmentu územného rozvoja európských štátov. Územnéplány.sk [online]. Dostupné z: https://www.uzemneplany.sk/co-je-to-uzemny-plan [cit.: 15.01.2021].

ÚNMS SR. 2006. Prepravné služby. Logistika mesta. Pokyny na definíciu prístupu do centra mesta. STN EN 14892, Bratislava

Wei, H.; Li. A.; Jia, N. 2020. Research on Optimization and Design of Sustainable Urban Underground Logistics Network Frame-work. Sustainability, 12, 9147. Dostupné z: https://doi.org/10.3390/su12219147 